\title{
ウェアラブルデバイスの市場規模と今後の展開
}

\author{
賀川 勝*
}

\section{Market Size and Future Development of the Wearabledevice}

\author{
Suguru KAGAWA*
}

* 株式会社矢野経済研究所（† 164-8620 東京都中野区本町 2-46-2 中野坂上セントラルビル )
*Yano Research Institute Ltd. (Nakanosakaue Central Bldg. 2-46-2 Honcho, Nakano-ku, Tokyo 164-8620)

\section{1. 成熟化が進む携帯電話サービスの現状と IoT 時代 に求められる通信サービス}

国連の人口統計によれば, 2014 年末における世界の人口 は 72 億 4,400 万人に達した。それに対して世界の携帯電話 契約数は 74 億 9,487 万 5,000 契約 (矢野経済研究所推計)

で，人口普及率は $103.5 \%$ に達している。

これまで携帯電話市場を牽引してきた BRICS（ブラジル， ロシア，インド，中国）市場における契約数増加ペースの 鈍化が顕著となっており，BRICS に替わり現在は ASEAN, 中南米, アフリカ諸国のウェイトが高まる見通しである。

2020 年に拈ける世界の携帯電話契約数は 87 億 6,924 万契 約（人口普及率 $113.6 \%$ ）への増加を見込んでいる（矢野経 済研究所推計)。

2007 年に (米) Appleのスマートフォン「iPhone」が発 売されて以降, スマートフォン市場の本格的普及に合わせ て通信インフラについても第三世代携带電話サービス (3G/3.5G) が世界中で普及した。また， 2012 年以降，第四 世代携帯電話サービス $(4 \mathrm{G})$ が本格的に立ち上がっており,

ワイヤレス・ブロードバンドの環境整備は急速に進んだ。

スマートフォンの普及に伴い，インターネット利用人口 も爆発的に増加した。場所や時間を問わず気軽にインター ネットが利用できるようになったことでインターネット サービスも急速に進化しており, FaceBookや Twitter, LINE に代表されるソーシャルネットワークサービスも爆発的に 普及している。インターネットのテクノロジやビジネスモ デルも進化を続けており, クラウドサービス, O2O (Online to Offline), ビッグデータと新たなトレンドが生まれ, 進化 を続けている。

最近では IoT (Internet of Things) に代表される「モノのイ ンターネット化」が注目されはじめている。「ウェアラブル デバイス」はIoT の中で最も注目を集めているデバイスで ある。

IoT はこれまでのモバイルインターネットで提供されて きた高速・大容量のモバイルデータ通信サービスは必ずし
も必要とされない。必要とされるのは従来技術とは真逆の 多頻度, 小容量, 省エネルギな通信サービスである。IoT を実現する通信環境として, BluetoothSMART (Bluetooth Low Energy), NFC, ZigBee に代表される近距離無線規格の採用 が広まっているが, これら近距離無線規格はスマートフォ ンなど，ホスト端末との連携が前提となっている。しか し, 将来的にIoT 端末が単独でネット接続することも想定 されるため, 第五世代通信サービス $(5 \mathrm{G})$ では IoT に最適化 されたシステムの導入も検討されている。

\section{2. ポスト・スマートフォンとして注目されるウェア ラブルデバイス}

2014 年における世界のハンドセット（フィーチャーフォ ンとスマートフォンの累計）出荷台数は 18 億 5,459 万台 (矢野経済研究所推計) で 2013 年実績 17 億 5,344 万台（同） を 1 億台強上回った。2014 年における世界のスマートフォ ン出荷台数は 13 億 4,246万台（同）で 2013 年実績 11 億 2,129 万台（同）を 2 億 2,000 万台増加した。2013 年にス マートフォンの出荷台数がフィーチャーフォンを上回って 以降，スマートフォンへのシフトが進むものの，フィー チャーフォンの出荷台数が急減しており, ハンドセット全 体の出荷台数は今後鈍化が見込まれる。

これまでスマートフォン市場を牽引してきたハイエンド 機（400 ドル上）の成長は鈍化が見込まれ，今後の成長 は新興国をターゲットとしたローエンド機（200ドル以下） の構成比が高まる見通しである。特に低所得者をターゲッ トにした 100 ドル未満の超低価格スマートフォンも開発さ れ, 南アジア, 中近東, 中南米やアフリカ市場にも導入が 進んでいる。

スマートフォン市場ではこれまで（韓）サムスン電子， Appleの 2 強による寡占状態となっていたが, 新興メーカ を含む中国企業の出荷台数が急増しており，聯想，華為技 術, 小米, ZTE (中興通迅), CoolPad (酷派), TCL (Alcatel) といった企業の存在感が高まっている。

既存メーカの多くはスマートフォンの機能, 価格面での 
差別化はもはや図れなくなっている。最近の傾向としては デザインを含めた商品企画に加え, ソーシャルメディア, クラウドサービス, 周辺機器との連携に差別化要素を見出 そうとしている。そのような状況下でメーカ各社が注力し 始めているのがウェアラブルデバイスである。

\section{3. ウェアラブルデバイスの概要}

「ウェアラブルデバイス」は身体に直接装着して使用する 機器全般を指すが, バイタルデータや行動履歴を送信し, クラウドサービスやソーシャルメディアと連携が可能な情 報通信機器としての機能を持つ製品が該当する。数ある ウェアラブルデバイスの中で大きな注目を集めているのが リストバンド型機器の「スマートウォッチ」,「スマートバ ンド」䇽よび, 眼鏡型機器の「スマートグラス」である。 その他指輪型, ネックレス型, 衣類型, 靴型や, グリップ 型（テニスラケット，ゴルフクラブのグリップ部に装着） が存在する（図 1)。

リストバンド型製品は以前より存在していたものの，本 格的なネット接続機能, 機器間連携機能を搭載し始めたの は，2012 年以降である。

スマートグラスは市販化された製品が非常に少ない。ス マートグラスと非常に近い製品としてヘッドマウントディ スプレイ（以下 HMD）が存在するが, HMD は没入型ディ スプレイとして主に $\mathrm{AV}$ 機器・ゲーム用ディスプレイ, バー チャルリアリティ(VR) 用ディスプレイとして市販されて いる。

ウェアラブルデバイスが生まれた背景には, 半導体や IT 技術の進化による影響が非常に大きい。21 世紀に入りパソ コン, 携带電話などの情報通信機器市場が急拡大した結 果, 液晶ディスプレイ, CPU, メモリに代表される半導 体，3G/4G，WiFi，Bluetooth といった通信技術の技術革新 が急速に進んだ結果, 高性能化, 小型化, 低価格化, 沉用 化が一気に進み, その経験がウェアラブルデバイス開発に

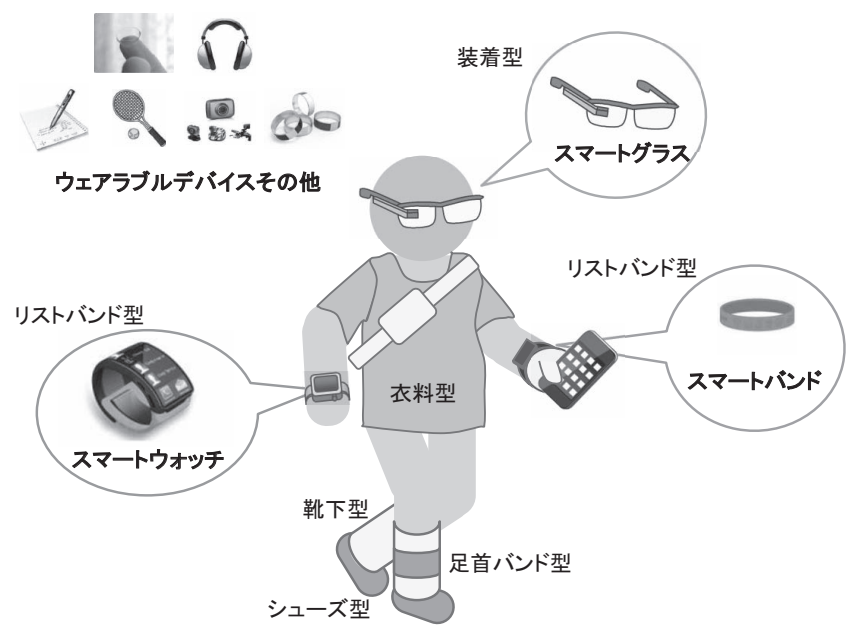

図 1. 主なウェアラブルデバイス
生かされている。

\section{4. スマートウォッチの概要}

スマートウォッチは腕時計型の小型コンピュータ端末の 総称で, ハードウェアの構成として,

(1)スマートフォンと同等の CPU と専用 OS を搭載した製 品

(2)組込型マイコンを搭載した製品

(3)クォーツ型腕時計をベースに開発された製品 の 3 種が存在するが，将来的には CPU・OS を搭載した製 品に集約される可能性が高い。また，インターネット（ク ラウド, ソーシャルメディア）への接続手段としてスマー トフォンの周辺機器として機能する「スマートフォン連携 型」。通信モジュールを搭載し単独でインターネットの接続 が可能な「オールインワン（スタンドアローン）型」に大 別される。市販されているスマートウォッチの多くはス マートフォン連携型である。

スマートウォッチの主な機能として

(1) スマートフォンの補助（SNS, コミュニケーションを 含む)

(2) 時計

(3) バイタルデータ測定機能

(4) 音声検索などの入力装置

などが挙げられ，将来的にはNFCを搭載しゲート入場や入 退室管理，決済端末としての活用が期待されている（図2）。

スマートウォッチ市場へは, 大手携带電話メーカの多く が参入している。最大手のサムスン電子が 2013 年にスマー トウォッチ市場に本格参入したのを手始めに，2014 年には (米) Google がスマートウォッチ向けプラットフォーム 「Android Wear」の提供を開始したことで参入が相次いだ。 さらに 2015 年春季には Apple が「Apple Watch」で市場に 参入している。また，スイスの高級腕時計メーカ TAG

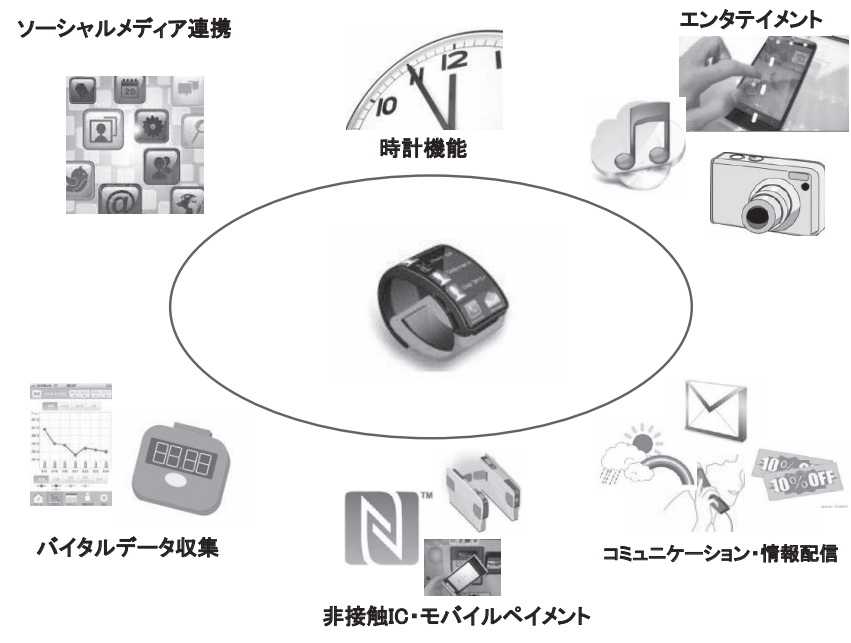

矢野経済研究所作成

図 2. スマートウォッチの主要機能 
Heuer が (米) Intel と共同でスマートウォッチの開発に乗 り出している。

\section{5. スマートバンドの概要}

スマートバンドは活動量計, 歩数計, 睡眠計といったへ ルスケア・セルフケア機器をスマートフォンなどと連携 し，クラウドサービスへの接続を可能とした製品である。 機能面ではバイタルデータの収集に特化しているため, 構 造はシンプルで低価格な製品が多いのが特徵である。リス トバンド型とクリップ型の製品に大別される。

スマートバンド市場は 2011 年頃から（米）Fitbit, （米） JAWBONE といったベンチャー企業が新規参入し市場での 主導権を握った。従来からセルフケア機器を手掛ける企業 やアウトドアスポーツ向け機器を手掛けるメーカも参入し ている。

中国のスマートフォンメーカXiaomi（小米）も2014 年 に低価格スマートバンド「MiBand」を導入し，同社のス マートフォン人気との相乗効果で急成長を遂げている。

\section{6. スマートグラスの概要}

スマートグラスは眼鏡型の小型コンピュータ・ディスプ レイ端末の総称で 2013 年に Google が「GoogleGlass」を発 表し注目を集めた。同端末は Google カーの開発を手掛ける Google XLab によって開発され，2013 年にアメリカ内の開 発者向けに少量が販売された。

スマートグラスは主に音声コマンドで動作する。メガネ のレンズ部にあたる透過型デイスプレイにコンテンツを表 示する。AR (仮想現実) の投影が可能でこれまでに無い表 現が可能である。また, 一部の製品はカメラを搭載してお り, 視線とリンクした写真・動画撮影が可能なため, アク ションカメラ的な使い方が可能である（図 3)。

スマートグラス向けアプリケーションに多くのアプリ ケーションが開発されており, 工場の製造現場や災害救 助, 医療現場などで「ハンズフリー化」を促す用途, 警 察, サービス産業などで「現場の可視化」を実現する用途 に有意性が認められている。しかし，開発に於いて技術的 な課題や, 法制面での整備の必要性が生じるなど課題や問 題が山積みで, 参入企業はごく少数に限定されている。

一方で，スマートグラスと類似のカテゴリの製品でヘッ ドマウントディスプレイ（以下 HMD）が存在する。 HMD は没入型のディスプレイ装置で, スマートグラスよりも仕 掛けが大掛かりであるものの, $\mathrm{AV}$ 機器・ゲーム用ディス プレイ，バーチャルリアリティ(VR)，3D 映像の投影に特 化している点がスマートグラスと異なる。市場規模は小さ いものの，1990 年代よりコンシューマ市場および業務用製 品が市販されている。サムスン電子, LG 電子はスマート フォンをHMD として活用する HMD を製品化している。

HMD の大手メーカである SONY は同社が手掛けてきた

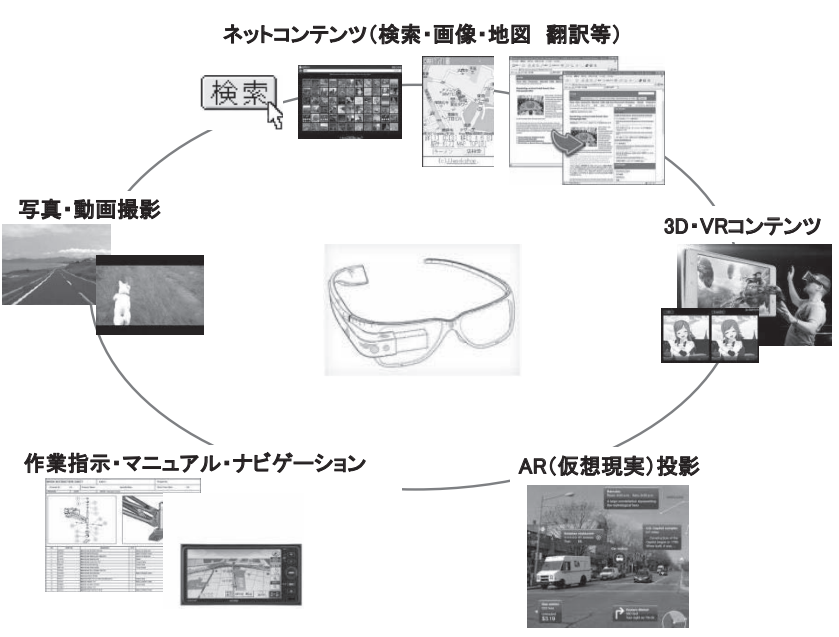

矢野経済研究所作成

図 3. スマートグラス (HMD) の主要機能

HMD 事業の収束を発表したものの, 子会社でゲームコン ソール「PlayStation」を手掛けるソニーコンピュータエン タテイメントが開発を進める「Morpheus（モーフィアス）」 を 2016 年に市場導入することを表明している。さらに (米) Microsoft も同社のゲームコンソール「X-BOX」向け にHMD の開発を進めている。

\section{7. ウェアラブルデバイスの課題・問題点}

ウェアラブルデバイスへの期待は大きいものの，発展途 上にあるため普及にあたっての課題・問題点を数多く抱え ている。主なものとして下記が挙げられる（図 4）。

（1) 情報の安全性，プライバシー，七キュリティの確保

(2) 耐久性・信頼性の確保

(3) インターフェースの熟成

(4) 製品コンセプト・ビジネスモデル

(5)最適なハードウェア構成

(6) 開発者コミュニティ, SDK

(7) 医療分野に付随する問題

(1)安全性, プライバシー, セキュリティの問題は

(a) 素材アレルギー・発熱問題などに代表される安全性に 起因する問題,「歩きスマホ」に起因するユーザのモ ラルに起因する問題

(b) カメラを使用した盗撮行為に代表される不正行為や公 共の場所での利用の是非

(c) ウィルス感染やデータ流出に起因するセキュリティ面 の問題

に大別される。特にスマートグラスは視界に捉えられた人 物のソーシャルメディアの利用状況を含む個人情報が無作 為にディスプレイ上に表示される懸念や自動車運転中にお ける安全性が問題視されている。Google がスマートグラス のコンシューマ市場向けの導入を一旦白紙化し，業務用途 に修正したのはこれらの問題が大きく影響している。

(2)耐久性の確保について, ウェアラブルデバイスは既存 
の腕時計・メガネと異なり情報通信機器であり, 耐久性や 製品寿命は短期である。

一部のスマートウォッチ製品では充電端子が皮膚に触れ る面に配置された為, 汗で接点が腐食した事例や, スマー トグラスに搭載されたバッテリが発熱し, 顔面に軽い火傷 を負った事例が報告されるなど安全性に直結する問題も抱 える。

ウェアラブルデバイスは発展途上であり, 開発が進むこ とでこれらの問題は解決に向かう筈である。

(3)インターフェースの熟成について, ウェアラブルデバ イスでは主にタッチパネルや音声入力が用いられているも のの, 既存製品向けに開発されたインターフェースの改良 に留まっており, ウェアラブルデバイスに最適化されたも のではない。

ウェアラブルデバイス向けにジェスチャー操作や視線認 識, $\mathrm{AR}$ キーボードなどの最適化されたインターフェース の開発も進められている。

(4)製品コンセプト・ビジネスモデルについて, ウェアラ ブルデバイスは既存の腕時計（ウォッチ）やメガネ・サン グラスと比較するとデザイン性, 嗜好性, ブランドが持つ 伝統といった面で大きく劣る。特に高級腕時計は宝飾品と しての要素も持ち合わせているため, スマートウォッチが 持つ機能性が評価されても高級腕時計の代わりとはなり得 ないと考えられている。またトレッキングや, ランニン グ・スポーツ用途など特定分野に特化した腕時計が存在す るが, 機能面でスマートウォッチと競合するものの, 耐久 性や消費電力などの面でスマートウォッチは足元にも及ば ない。

とはいえ，伝統を持つ高級ブランド企業やスポーツ ウォッチを手掛けるメーカがスマートウォッチの開発を手 掛け始めていることから, 市場の成長に伴い前述の問題は 解消されていく可能性が高い。

(5)最適化されたハードウェア構成について, ウェアラブ ルデバイスが今後普及するには省スペース, 低消費電力, 低価格を実現する必要があり, OS も含めたプラットフォー ム化が必要である。Google はウェアラブルデバイス向けプ ラットフォーム「Android Wear」を発表し, チップセット ベンダ各社が Android Wearへの対応を進めている。それに 引っ張られる形で部品メーカ各社の本格参入が期待され ディスプレイ, バッテリなど, ウェアラブルデバイス時代 に向けた要素技術の開発が進み, 安定供給とコストダウン が進むことが期待される。将来的には EMS, ODM を通じ て時計メーカやファッション・スポーツブランドによる参 入の可能性も期待される。

(6)開発者コミュニティ, SDK について, スマートフォン をはじめとする IT 機器の普及に於いて, アプリケーション は非常に重要な役割を果たす。現在, アプリ開発者のリ ソースはユーザ数が多いスマートフォン (Android, iOS) 向

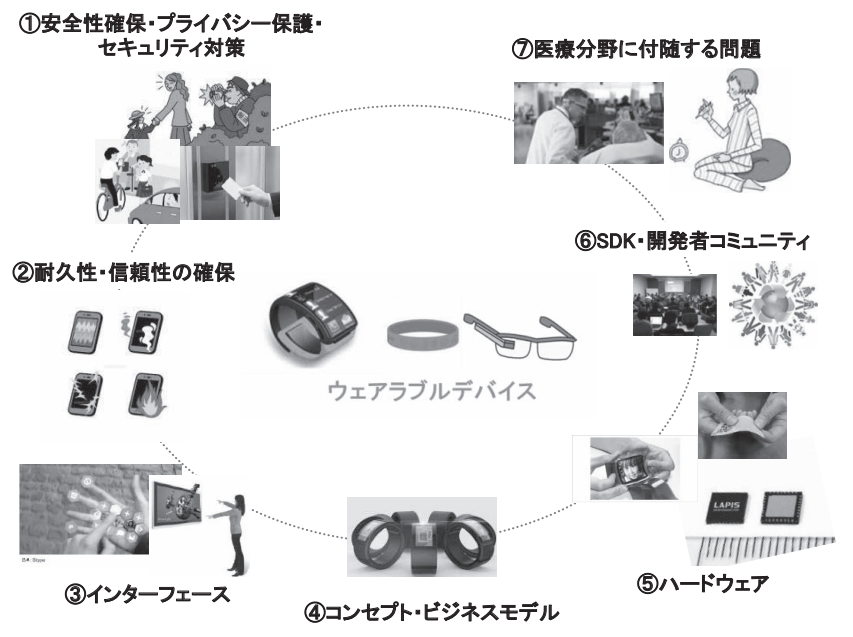

矢野経済研究所作成

図 4. ウェアラブルデバイスが抱える課題

けに集中しており, ウェアラブルデバイス向けの開発に手 が回っていないのが実情である。しかし，ウェアラブルデ バイスの中でもスマートウォッチ向けについては Android, WatchOS (Apple Watch) 向けに開発キット (SDK) が配布され ている。中でも WatchOSについては「HealthKit」「HomeKit」 といった開発キットも配布されている。今後スマート ウォッチ普及に伴いアプリケーション増加が期待できるも のの, 2015 年 7 月現在は, スクリーン (文字盤) のカスタ マイズアプリが大半を占めているに過ぎない。

(7)医療分野に付随する問題について, 現在のウェアラブ ルデバイスはセルフケア, ヘルスケア分野で利用され, 活 動量計, 歩数計, 睡眠計といった機能に加え, 脈拍の測定 は可能である。しかし, 血圧, 体温といった医療における 基礎データとなる類のバイタルデータ収集は不可能であ る。また, 医療データとして収集・活用する場合, 取得し たデータが法制度, 規定により定められた条件下で取得さ れたものかどうか, 取得デー夕の種類, 計測時間, 数量が 適切なのかなど, 業界内だけでなく, 実際に利用するユー ザに対しても周知徹底する必要がある。ウェアラブルデバ イスは遠隔医療に於いて有効なデバイスではあるものの, 実現には越えねばならないハードルは多い。

\section{8. ウェアラブルデバイスの国内市場規模}

2014 年度のウェアラブルデバイスの国内市場規模は 139 万 8,000 台 (矢野経済研究所推計) だった。製品カテゴリ別で はスマートウォッチが 21 万 2,000台（同，スマートバン ドが 106 万台（同），スマートグラス（HMD 含む）が 12 万 6,000 台（同），その他 1 万 2,000台（同）だった（図 5)。

国内のウェアラブルデバイス市場はスマートウォッチの 注目度は高まっているものの, 実際にはスマートバンドが 牽引している。スマートグラス／HMD は大半が HMD に よって占められている。 
2015 年度ウェアラブルデバイスの国内市場規模は 252 万 6,000 台（同）が見达まれる。製品カテゴリ別ではスマート ウォッチが 71 万台 (同), スマートバンドが 166 万台 (同)，スマートグラス（HMD含む）が 15 万 6,000 台 (同)，その他 2 万台（同）となっている。

2015 年度の国内市場についてもスマートバンドが市場を 星引する。大手通信事業者がウェアラブルデバイスへの取 り組みを強化しており, ヘルスケアサービスの展開と併せ てスマートバンドの取り扱い数量増加が見达まれる。

スマートウォッチは 2015 年 4 月に Apple「Apple Watch」 が発売された。販路が限定されているものの, 市場の関心 は高く，スマートウォッチ市場の牽引役が期待されている。

スマートグラスはセイコーエプソン「モベリオ (moverio) BT-200」以外に有力な製品は存在せず, Google $\lceil$ GoogleGlass」の国内市場導入の見通しが立たないことも あり, 本格的な市場の立ち上がりは期待できない。HMDに ついても最大手の SONY が一時的に縮小したため, 前年実 績割れの可能性がある。

2016 年以降のウェアラブルデバイス市場は緩やかに拡大 する見通しで，2018 年度の国内市場規模は 775 万台（同） を予測している。

ウェアラブルデバイス市場は通信事業者やヘルスケア サービス利用を前提としたスマートバンド中心に展開する ものの, 製品価格が安価であることから, 顧客獲得の一環 としてばら撒きビジネスとなる危険性を持つ。大きな動き として注目されるのは厚生労働省が進める医療制度改革の 行方によっては国内に於いてもセルフケア・ヘルスケア サービスが本格的に立ち上がる可能性を持つ。

スマートウォッチについて, Apple Watchの注目度は高 く, 仮に通信事業者が取り扱いを本格化させ, iPhone との セット販売を行うようになれば安価に提供され, 市場が急 拡大する可能性があるものの，市場に製品が本格的に出回

単位: $\times 1,000$ 台

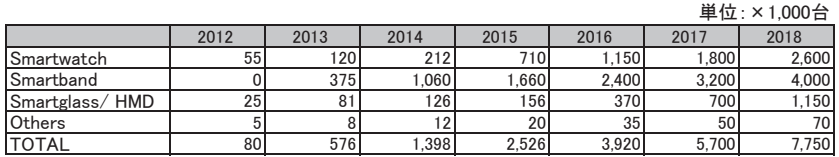

暦年(1-12月)ベース 矢野経済研究所推計

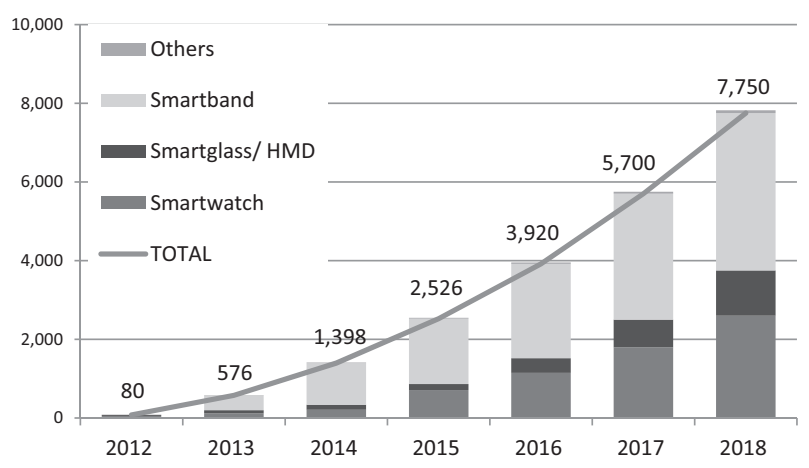

図 5. 国内ウェアラブルデバイス市場規模
り始めるためにはキラーとなるアプリケーションの存在が 不可欠である。

スマートグラスについては，市場へ参入する企業は限定 されている現在, 販売価格が安価になる可能性は低く, 市 場拡大は望みにくい状況である。HMD に関しては2016 年 以降, SONY, MicroSoftによるゲームコンソール向けHMD の導入が見込まれ, Oculus「Lift」の市販化計画と併せて普 及への道筋が見え始めている。

\section{9. ウェアラブルデバイスの世界市場規模}

2014 年のウェアラブルデバイスの世界市場規模は 2,170 万 5,000 台（矢野経済研究所推計）だった。製品カテゴリ 別ではスマートウォッチが 530 万台（同），スマートバンド が 1,562 万台（同），スマートグラス（HMD 含む）が 68 万 5,000 台（同），その他 10 万台（同）だった（図 6)。

ウェアラブルデバイスはアメリカ市場が世界最大であ る。人口が多いことに加え，ウェアラブルデバイスを手掛 けるベンチャー企業が数多く存在すること，特にアメリカ では医療保険改革制度（オバマケア）施行に合わせて，企 業の健康保険組合と保険会社が手を組み，ウェアラブルデ バイスを活用したヘルスケアの取り組みが始まった。Fitbit やJAWBONE といったスマートバンドを手掛けるメーカは この流れに乗り出荷台数を急増させた。

中国についても，ウェアラブルデバイスの一大市場であ る。広東省深圳市にある経済特区では PC，スマートフォン に代表される IT 機器の開発・製造を手掛ける企業が数多く 存在しており, IT 機器開発のノウハウを生かし, ウェアラ ブルデバイスの開発を手掛けている。2014 年に出荷された スマートウォッチ，スマートバンド製品の 3 割程度深圳で 製造されたものと推定される。その影響もあり，中国国内 市場向けに多種多様なスマートウォッチ, スマートバンド 製品が流通している。

スマートウォッチ市場について，サムスン電子はTizenOS を搭載した「Gear」シリーズを導入したものの，販売では 苦戦を強いられている。Android スマートフォンを手掛け るメーカ各社は Android Wear を採用したスマートウォッチ を導入し，ビジネス拡大のチャンスを狙っている。市場の ベンチマークとなる製品は Apple「Apple Watch」であるこ とに疑いの余地はないものの, 供給の問題も含め初年度と なる 2015 年における出荷台数は 1,000 万台から 1,500 万台 に間になるとみられている。

スマートバンドは市場参入の障壁が低いことから既に多 くの企業が参入している。現在はアメリカ市場が最も大き く, Fitbitが高いシェアを占めている。しかし，Xiaomi（小 米）のケースに見られるようにスマートグラスを手掛ける メーカから競争力が高い製品が発売されると市場シェアは 大きく書き換えられる可能性を持つ。

スマートグラスは「GoogleGlass」の開発が見直されたこ 

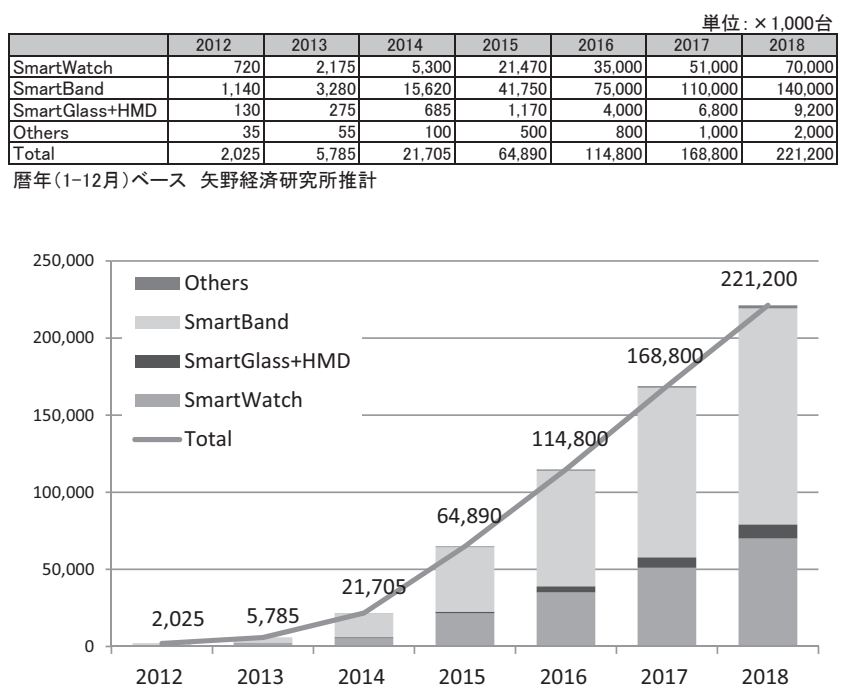

図 6. 世界ウェアラブルデバイス市場規模

とで将来性について不透明な状況にある。

最大の問題は「プライバシー」にあり, 法制度の整備を 含めてクリアにならない限り, 本格的な普及は期待できな い状況にある。

\section{0. ウェアラブルデバイス市場の見通し}

(米) Fitbitは 2015 年 6 月に NY 証券取引所で IPO を実施 し，日本円で約 900 億円の資金調達に成功し，アメリカ IT 企業に扔ける過去最大規模の IPO となった。今後もウェア ラブルデバイスを手掛ける企業の IPO が続くことが予想さ れ, ウェアラブルデバイスは IT 業界に於ける期待の成長株 であることが裏付けられた。

また, Googleによるスマートホーム機器開発ベンチャー $\lceil\mathrm{Nest}$ 買収や，FacebookによるHMDメーカ「OculusVR」 買収に代表されるように大手 IT 企業のウェアラブルデバイ 又関連企業買収は数年後の情報通信産業を見越した投資で あり, ウェアラブルデバイス市場への期待は「常時身に着 ける特性を生かしながらさまざまな機器やサービスと接 続・連携するハブ的役割が求められている」とみることが 出来る。

中でも Google は Android スマートフォンで収集した情報 を含めたビッグデー夕により構築したデータベースを基に $\mathrm{AI}$ (人口知能) の開発を手掛けて抢り, 自動運転カーやロ ボット開発に生かされる予定である。Google はウェアラブ ルデバイスについてもデータ収集に活用するのは間違いな く, Android Wearが果たす役割は決して小さくない。

現在, Web とリアル, 業界・業種を問わずあらゆる企業 がデジタル化とグローバル化の波に晒されている。今後の 厳しい競争を勝ち残るには逸早くプラットフォーマーにな ることが求められ, 自らが主導的に展開していく必要があ
る。スマートフォンを含めた情報通信産業全般に於いて現 在の勝ち組企業であるアメリカの IT 企業のビジネスモデル はプラットフォーム化が前提となっていた。今後もアメリ カのIT 企業がこのままさらなる成長を遂げるのか, 日本や アジアから新たな革命が生まれるのか，現在はその瀬戸際 の状況にあり, ウェアラブルデバイスのビジネスは重要な ピースとなるのは確実である。

将来的には大きな可能性を持つウェアラブルデバイスだ が直近の問題として, 購入当初は物珍しさも手伝ってウェ アラブルデバイスを利用してみるものの, 不便さやユーザ メリットの少なさを感じて利用を止めてしまうユーザは少 なくない。スマートフォンは万能であるが故に広く普及し たが， ウェアラブルデバイスはスマートフォンと比較する と能力, 多様性に欠ける機器であるため, 如何にユーザを 飽きさせずに継続して利用して貫えるようにするかが大き な課題である。この課題を解決できなければウェアラブル デバイス市場への大きな期待は大きく萎むことになってし まうだろう。

2015 年最大の注目製品といって過言ではない Apple Watch について，市場は Apple がウェアラブルデバイスに対して どのような回答を示すのかに大きな関心を寄せたが，アプ リケーションや連携する機器が不足し，同製品が持つポテ ンシャルをフルに発揮できていないこともあり，市場の期 待值を下回っていると判断できる。明確な回答を得るまで あと 1 ～年待たなくてはならないが，その頃には Appleが 巧みなビジネスモデルを構築し，金融サービスを含めたプ ラットフォームが形成され，Appleに市場を抑えられてし まう状況になっているかもしれない。

(2015.7.13- 受理)

\section{文献}

1) 矢野経済研究所：“2014 年版 スマートフォン連携サービ 又・機器・NFC 市場展望”

2) 矢野経済研究所: “2015-2016 携带電話世界市場動向調查 —モバイル事業者の戦略と主要国分析一”

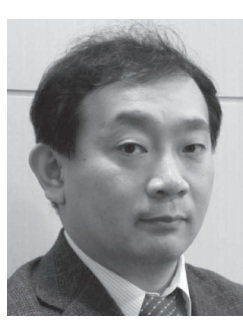

賀川 勝（かがわすぐる）

著者紹介 2000 年 4 月に矢野経済研究所入社後, 主に国内. グローバルの移動体通信の市場調查・分析業務を 担当。近年は ODM・EMS の動向を中心にスマー トフォン・タブレット・ウェアラブルデバイスと いった最先端のデバイスの動向などを研究テーマ に活動している。

また，調査・分析業務だけでなく，市場進出支 援，新規事業支援，地域振興・産業振興支援など のコンサルティング業務も手がけている。

本記事の著作権は矢野経済研究所に帰属しますが, 本学会は全ての メディアに扔ける出版，掲載，配布の許可を得て掲載しています。 